\title{
Genetic diversity of hepatitis B co-infection with hepatitis C, D and E viruses among Malaysian chronic hepatitis B patients
}

\author{
Shuaibu Abdullahi Huduㄹ, Mohd Taib Niazlin², Syafinaz Amin Nordin² , Soek Siam Tan², \\ Haniza Omar ${ }^{3}$, Hamiza Shahar ${ }^{3}$, Noor Aliza Mutalib ${ }^{3}$, Zamberi Sekawi ${ }^{2}$
}

1. Department of Medical Microbiology and Parasitology, Faculty of Basic Medical Sciences, College of Health Sciences, Usmanu Danfodiyo University Sokoto, 840232 Sokoto State, Nigeria.

2. Department of Medical Microbiology and Parasitology, Faculty of Medicine and Health Sciences, University Putra Malaysia.

3. Department of Hepatology, Selayang Hospital, Lebuh Selayang Batu Cave Selangor, Malaysia.

\begin{abstract}
Background: Hepatitis B virus co-infection with other strains of viral hepatitis is associated with increased risk of liver cirrhosis and hepatic decompensation.

Objectives: This is a prevalence study that assessed the genetic diversity of chronic hepatitis B patients and coinfection.

Methods: Chronic hepatitis B patients enrolled in this study were tested for antibodies of other hepatitis viruses using ELISA kits. Patient clinical profiles were collected and partial genes of HBV, HCV, and HEV were amplified, sequenced, and analyzed using phylogenetic analysis. The associations between variables were determined using the chi-squared test.

Results: Of the 82 patients recruited for this study, $53.7 \%$ were non-cirrhotic, $22.0 \%$ cirrhotic, $20.7 \%$ acute flare and $3.7 \%$ hepatocellular carcinoma. Majority (58\%) of patients had a high level of ALT ( $\geq 34 \mathrm{U} / \mathrm{L})$. Sequence analysis showed HBV $(63.9 \%)$ belonged to genotype $\mathrm{B}, \mathrm{HEV}$ belonged to genotype 4 while HCV belonged to genotype $3 \mathrm{a}$ and the genotypes were found to be significantly associated with the clinical stage of the patients $\left(\chi^{2}=56.632 ; \mathrm{p}<0.01\right)$. Similarly, Hepatitis $\mathrm{B}$ e antigen was also found to be significantly associated with the clinical stage of infection $\left(\chi^{2}=51.952 ; \mathrm{p}<0.01\right)$.

Conclusion: This study revealed that genetic diversity was found to have a significant impact on the severity of infection.

Keywords: Hepatitis co-infection, Hepatitis genetic diversity, Malaysia.

DOI: https://dx.doi.org/10.4314/ahs.v18i4.33

Cite as: Hudu SA, Niazlin MT, Nordin SA, Tan SS, Omar H, Shahar H, Mutalib NA, Sekawi Z. Genetic diversity of hepatitis B co-infection with hepatitis C, D and E viruses among Malaysian chronic hepatitis B patients. Afri Health Sci. 2018;18(4): 1117-1133. bttps://dx.doi. org/10.4314/abs.v18i4.33
\end{abstract}

\section{Introduction}

Hepatitis B virus (HBV) causes a globally endemic viral

\section{Corresponding author:}

Zamberi Sekawi,

Department of Medical Microbiology

and Parasitology, Faculty of Medicine

and Health Sciences

Universiti Putra Malaysia

43400 UPM Serdang

Selangor, Malaysia

Tel: 0398472365

Fax: 0389413802

Email: zamberi@upm.edu.my infection with an estimated 240 million chronically infected patients. Hepatitis B causes an annual mortality of 780,000 of which 650,000 deaths occur in chronically infected patients secondary to liver cirrhosis and cancer; the remaining 130,000 deaths are a result of acute hepatitis B infection. In Malaysia, 1 million people chronically infected with hepatitis B and 453,700 people were living with HCV infection. However, Chronic hepatitis B accounts for more than $80 \%$ of the hepatocellular carcinoma (HCC) cases seen in Malaysia, and is the $3^{\text {rd }}$ most common malignant neoplasm and among the 10 leading causes of death. ${ }^{1}$ Hepatocellular carcinoma (HCC) is one of the most common cancers globally and is highly related to viral hepatitis, especially hepatitis B and $C^{2}$. Hepatitis $\mathrm{B}$ genome diversity is globally influenced by both 
phenotypic and genotypic variability. Phenotypic variability often develops in the presence of selective pressure mounted by the immune system of the host during vaccination or therapy. Genotypic variability often evolves in the absence of such selective pressure.

Hepatitis $\mathrm{C}$ virus (HCV) is an important underlying factor in the development of liver diseases and contributes to $25 \%$ of liver cancer cases globally ${ }^{3}$. The prevalence of hepatitis $C$ virus in Asia has been reported to be $2 \%$, with high genetic variability ${ }^{4,5}$. The predominant genotype in SouthEast Asia is genotype 6, while genotypes $1-3$ are distributed globally ${ }^{6-8}$. Hepatitis D virus (HDV), conversely, is an unusual single stranded RNA virus that is devoid of an envelope protein and depends on HBV for its enveloped protein?. The predominant HDV genotype in Asia is genotype 2, most especially in East Asia, while genotype 1 has a global distribution; the remaining six genotypes are distributed in other geographical areas ${ }^{10}$. Hepatitis D virus has also been reported as an important cause of acute and chronic liver disease in several regions of the world ${ }^{11}$.

Epidemics of hepatitis E virus (HEV) have been reported in Central and SouthEast Asia, the Middle East, Africa and other parts of the world ${ }^{12}$. Its transmission is predominantly feco-oral and can be zoonotic. HEV is a common cause of acute viral hepatitis globally ${ }^{13}$. HEV is associated with the development of acute-on-chronic liver failure and increased mortality among chronic liver disease patients ${ }^{14}$. Hepatitis C, D, and E, when present as a co-infection or super-infection in a chronic HBV patient, lead to more severe disease with higher mortality than in HBV mono-infection ${ }^{15,16}$. However, little is known on the effect of HBV co-infection with other viral hepatitis strains, most especially in Malaysia. As such, in this study, we assessed the prevalence of $\mathrm{HBV}, \mathrm{HCV}, \mathrm{HEV}$ genotypes in patients with HBV infection and the predominant co-infection with other hepatitis viruses and their different genotypes in relation to the clinical stage of infection.

\section{Materials and methods Study design}

This was an analytical cross-section, involving 82 patients with treatment naïve chronic hepatitis $B$ infection at the time of their first visit to the hepatology clinic.

\section{Patients recruitments}

Patients were recruited consecutively from the Hepatology Department, Selayang Hospital, Selangor which is a tertiary hepatology referral Centre in Malaysia.

\section{Sample and data collection}

Purposive (judgmental) sampling will be used for this study in which subjects will be picked on the basis of specific clinical and biochemical characteristics as determined by the physician. Blood samples were collected at the Hepatology Department at Hospital Selayang, Selangor, Malaysia, between May 2015 and May 2016. In total, 82 blood samples were collected from patients with chronic hepatitis B infection at the time of their initial presentation to the clinic. Sample size was determined using the sample size formula for estimating minimum sample size in cross-sectional study as described by Daniel W. Biostatistics: A Foundation for Analysis in the Health Sciences, $7^{\text {th }}$ edR Wiley. New York. 1999. The patients' plasma was separated from the blood immediately after collection, frozen and transported on ice to the Laboratory of Clinical and Molecular Virology at Universiti Putra Malaysia for further analysis. Hospital Selayang is a national tertiary referral center which specializes in managing patients with acute or chronic liver diseases. All samples were free of human immunodeficiency virus. All leftover samples were archived and anonymized. Patient biodata, clinical information such as presence of jaundice, easy fatigability and pruritus laboratory information such as liver function test and serum protein was collected via a proforma administered by the attending physician, after obtaining patient consent.

\section{Ethical considerations}

Ethical approval to conduct this study was obtained from the Ministry of Health Malaysia Medical Research and Ethics Committee (KKM/NIHSEC/ P15-63) as well as the Universiti Putra Malaysia Human Research Ethics Committee (UPM/TNCPI/RMC/JKEUPM/1.4.18.1/ F1). Consent was obtained from the respective patients who volunteered for the study by the attending physician.

\section{Serology screening}

Plasma samples from all patients were tested for hepatitis B surface antigen ( $\mathrm{HBsAg}$ ) using an ELISA kit (DRG International Inc. New Jersey, USA). Further tests for antibodies against hepatitis B surface antigen (anti-HBs), 
hepatitis B e antibody (anti-HBe), hepatitis B e antigen $(\mathrm{HBeAg})$ and hepatitis B core antigen (IgG and IgM anti-HBc) were carried out on all 82 plasma samples. All plasma samples were screened for hepatitis $\mathrm{C}, \mathrm{D}$ and $\mathrm{E}$ virus antibodies (anti-HDV, anti-HCV and anti-HEV) using ELISA kits (Novatein Biosciences, Woburn, MA), and for hepatitis E virus antibodies ( $\operatorname{IgG}$ and $\operatorname{IgM}$ ) (Wantai Bio-pharm., Beijing, China) according to manufacturer's instructions.

\section{Extraction of HBV DNA}

Hepatitis B viral DNA was extracted from plasma (200 $\mu \mathrm{l}$ ) using a QIAamp DNA blood mini kit according to the manufacturer's instructions (Qiagen Hilden, Germany). Briefly, $20 \mu \mathrm{l}$ of proteases was put into a $1.5 \mathrm{ml}$ tube after which $200 \mu$ l of plasma was added, followed by AL buffer (cell lysing buffer). The mixture was then vortexed and incubated for 10 minutes at $56^{\circ} \mathrm{C}$, after which $200 \mu \mathrm{l}$ of ethanol was added in order to enhance the precipitation of DNA trapped in the column. The trapped DNA was then washed with wash buffer AW1, followed by AW2 to eliminate impurities. Finally, the DNA was eluded with $40 \mu \mathrm{l}$ of elution buffer then stored at $-20^{\circ} \mathrm{C}$ until further analysis.

\section{HBV DNA amplification and sequencing}

Two sets of published primers were used for amplification of the hepatitis B small S gene from the stored DNA samples. The amplification was performed using nested PCR, in which extracted HBV DNA was used in the first round PCR, while the product of the first round was used as the template for the second round PCR. Both PCR amplification was done as described previously ${ }^{17}$. The products of amplification were analyzed using gel electrophoresis with a $1.5 \%$ agarose gel (Seakem LE, USA). Electrophoresis was performed at $80 \mathrm{~V}$ and $400 \mathrm{~A}$ for 45 min (Bio-Rad, USA). PCR products were visualized using a Gel Doc XR imager (Bio-Rad, USA) and the product size was determined by comparison to a DNA molecular marker (GeneDireX). The products were sequenced commercially by integrated DNA Technologies (IDT, Gemini Singapore). All our Malaysian sequences were deposited in GenBank under the accession numbers KX670217-KX670241 and KX682284-KX682340 for genotypes $\mathrm{C}$ and $\mathrm{B}$, respectively.

\section{RNA extraction}

Viral RNA was extracted from hepatitis C and E seropositive plasma samples using a high purity viral RNA extraction kit according to the manufacturer's instructions (Roche, Germany). Briefly, $400 \mu \mathrm{l}$ of binding buffer supplemented with poly A was put in a $1.5 \mathrm{ml}$ tube and then $200 \mu \mathrm{l}$ of plasma was added, thoroughly mixed and transferred into a high purity filter assembly. The mixture was incubated for 10 minutes at room temperature and centrifuged for 15 seconds at $800 \mathrm{x}$ g. The flow-through was discarded along with the collection tube and the upper filter tube was re-assembled with a new collection tube. The final elution step was performed by the addition of $50 \mu \mathrm{l}$ of elution buffer into the upper reservoir and centrifugation at $8000 \mathrm{x}$ g for $1 \mathrm{~min}$. The RNA sample was aliquoted, tested for purity and kept at $-70^{\circ} \mathrm{C}$ until further use.

\section{RNA purity and concentration}

The extracted RNA was subjected to purity and concentration checks. The optical density of the RNA sample was measured using a Nanodrop spectrophotometer according to the manufacturer's instructions. Absorbance ratios at A260/280 were obtained to determine the concentration and purity of the RNA. The quality of RNA is considered good when the A260/A280 ratio is within the range of 1.9 to 2.1 .

\section{RNA amplification and sequencing}

Viral RNA from both HCV and HEV were amplified by reverse transcriptase polymerase chain reaction (RT-PCR) using the Monster script reverse transcriptase kit (Epicenter Technologies Corp., Chicago, IL, USA) according to manufacturer's guide. Briefly, $0.5 \mathrm{ml}$ PCR tubes containing $10 \mu \mathrm{l}$ of viral RNA sample, $2 \mu \mathrm{l}$ of random primers and $3 \mu$ l of RNase-free water were incubated at $65^{\circ} \mathrm{C}$ for $1 \mathrm{~min}$ in a thermal cycler (Bio-Rad Laboratories, Inc. California USA). The heated samples were placed on ice immediately for $1 \mathrm{~min}$. Then $4 \mu \mathrm{l}$ of cDNA premix and $1 \mu \mathrm{l}$ of MonsterScript reverse transcriptase were added. The tube was mixed gently and incubated for $5 \mathrm{~min}$ at $37^{\circ} \mathrm{C}$, then heated at $45^{\circ} \mathrm{C}$ for $5 \mathrm{~min}$, then incubated for $40 \mathrm{~min}$ at $60^{\circ} \mathrm{C}$ in a thermal cycler (Bio-Rad Laboratories, Inc. California USA). The reaction was terminated by heating 
at $90^{\circ} \mathrm{C}$ for $5 \mathrm{~min}$, after which the samples were cooled on ice for $1 \mathrm{~min}$. The cDNA was extracted by brief centrifugation for $1 \mathrm{~min}$, and then samples were stored at $-30^{\circ} \mathrm{C}$ until used. Samples were amplified using published primers targeting HEV-ORF2, as described previously ${ }^{18}$. Similarly, HCV RNA was also amplified using published primers targeting HCV- NS5B. ${ }^{19}$ The PCR products for both HEV and HCV were analyzed using gel electrophoresis and visualized using a Gel Doc XR imager (Bio-Rad, USA). The amplified products were purified using the GF-1 PCR clean-up kit (Vivantis Technologies, USA) according to the manufacturer's instructions. The purified fragments and PCR products were sequenced commercially by integrated DNAT (IDT, Gemini Singapore). All our Malaysian HCV and HEV isolate sequences were deposited in GenBank under accession numbers KX449132 and KX426575-KX426582, respectively.

\section{Diversity and phylogenetic analysis}

Molecular Evolutionary Genetics Analysis version 7 (Mega7) software was used for sequence alignment via Clustal W. Phylogenetic analysis was done based on the Kimura two-parameter model inferred by the maximum likelihood method with the variation rate among gene sites modeled with a gamma distribution $(G)$. Reference sequences were selected from the GenBank database (http://www.ncbi.nih.gov). All our sequences were genotyped, sub-genotyped and serotyped by aligning with the S-gene, NS5B and ORF2 reference sequences of established genotypes, sub-genotypes and serotypes, respectively, from GenBank. The evolutionary history of the sequenced was also inferred by maximum likelihood.

\section{Results}

In this study, a total of 82 chronically infected patients were recruited from May 2015 to May 2016, of which
$59.8 \%(49 / 82)$ were male and 40.2\% (33/82) were female. The distribution according to ethnicity was 32.9\% (27/82) Malay, 62.2\% (51/82) Chinese, 3.7\% (3/82) Indian and $1.2 \%(1 / 82)$ Orang Asli. Half (41/82) of the patients were older than 50 year of age and only $11 \%$ (9/82) were below 30 years of age; the remaining 39\% $(32 / 82)$ of patients were between 30 and 49 years of age. The patients recruited for this study were classified into four clinical stages; non-cirrhotic $(53.7 \%)$, cirrhotic $(22.0 \%)$, acute flare $(20.7 \%)$ and hepatocellular carcinoma $(3.7 \%)$. All plasma samples were positive for $\mathrm{HBsAg}$, IgG anti-HBc, and the negative IgM anti-HBc. Majority, i.e. $52.4 \%(43 / 82)$ was positive for $\mathrm{HBeAg}$. Hepatitis B e antigen was found to be significantly associated with the clinical stage of infection $\left(\chi^{2}=51.952 ; \mathrm{p}<0.01\right)$. Hepatitis $\mathrm{E}$ virus IgG was found to be positive in 8 of the samples while Hepatitis $C$ virus $\operatorname{IgG}$ positive in only one sample and both were negative for IgM.

The viral hepatitis virus that were detected among the chronic hepatitis $\mathrm{B}$ patients are hepatitis $\mathrm{C}$ and $\mathrm{E}$ and the rate of the co-infection was found to be $9.8 \%(8 / 82)$ for $\mathrm{HBV}+\mathrm{HEV}$, and $1.2 \%(1 / 82)$ for $\mathrm{HBV}+\mathrm{HCV}$ All samples were tested negative for HDV while, greater part of them, $89 \%(73 / 82)$ present with hepatitis B mono-infections. Liver function tests revealed that the majority $(58 \%)$ of patients had an alanine aminotransferase (ALT) level ( $\geq 34 \mathrm{U} / \mathrm{L})$. Physical examinations showed jaundice as the most frequent clinical symptom, followed by easy fatigability. The Pearson chi-squared test revealed a strong positive correlation between the clinical stage of infection and the level of aspartate aminotransferase (AST) at $\mathrm{p}<0.01$ and jaundice $(\mathrm{p}<0.01)$. Likewise, alanine aminotransferase (ALT) was found to correlate moderately with clinical condition $(\mathrm{p}<0.01)$, as well as serum total bilirubin $(p<0.01)$. The total protein and albumin correlated negatively with the severity of infection (Table 1). 
Table 1: Clinical stage of infection (cirrhotic, non-cirrhotic, hepatocellular carcinoma and acute flare) correlated with clinical and laboratory findings

\begin{tabular}{|c|c|c|}
\hline \multirow[b]{2}{*}{ Clinical profile } & \multicolumn{2}{|c|}{ Clinical stage Pearson correlation } \\
\hline & Pearson's r & $P$-value \\
\hline Past medical and social history & 0.119 & 0.289 \\
\hline Serum bilirubin $(\mu \mathrm{mol} / \mathrm{l})$ & $0.563 * *$ & 0.000 \\
\hline Total protein $(\mathrm{g} / \mathrm{l})$ & $-0.390 * *$ & 0.001 \\
\hline Albumin $(g / 1)$ & $-0.562 * *$ & 0.000 \\
\hline $\operatorname{ALT}(\mathrm{U} / 1)$ & $0.483 * *$ & 0.000 \\
\hline AST (U/l) & $0.597 * *$ & 0.000 \\
\hline Jaundice & $0.681 * *$ & 0.000 \\
\hline Fibro scan & 0.13 & 0.401 \\
\hline Easy fatigability & $0.640 * *$ & 0.000 \\
\hline Pruritus & $0.373 * *$ & 0.001 \\
\hline Platelet count $\left(\times 10^{9} \mathrm{~g} / \mathrm{l}\right)$ & 0.015 & 0.901 \\
\hline
\end{tabular}

$\mathbf{U} / \mathbf{L}=$ units per liter; $\mathbf{g} / \mathbf{l}=$ gram per liter; ${ }^{* *}$ significant correlation at 0.01 (two-tailed) $\boldsymbol{\mu m o l} / \mathbf{l}=$ micromoles per liter; (-) =negative correlation

The hepatitis B virus DNA results revealed the amplification of the targeted small $S$ region of the surface protein, which was further confirmed by the sequencing results. The HBV sequences of the Malaysian isolates exhibited
$99 \%$ homology with identity ranging from 90 to $100 \%$. Phylogenetic analysis of the Malaysian HBV isolated revealed that the majority, i.e. $69.5 \%(57 / 82)$ of the isolates, were grouped together in a cluster with genotype B; the remaining 30.5\% (25/82) formed a cluster with genotype C (Fig 1). 


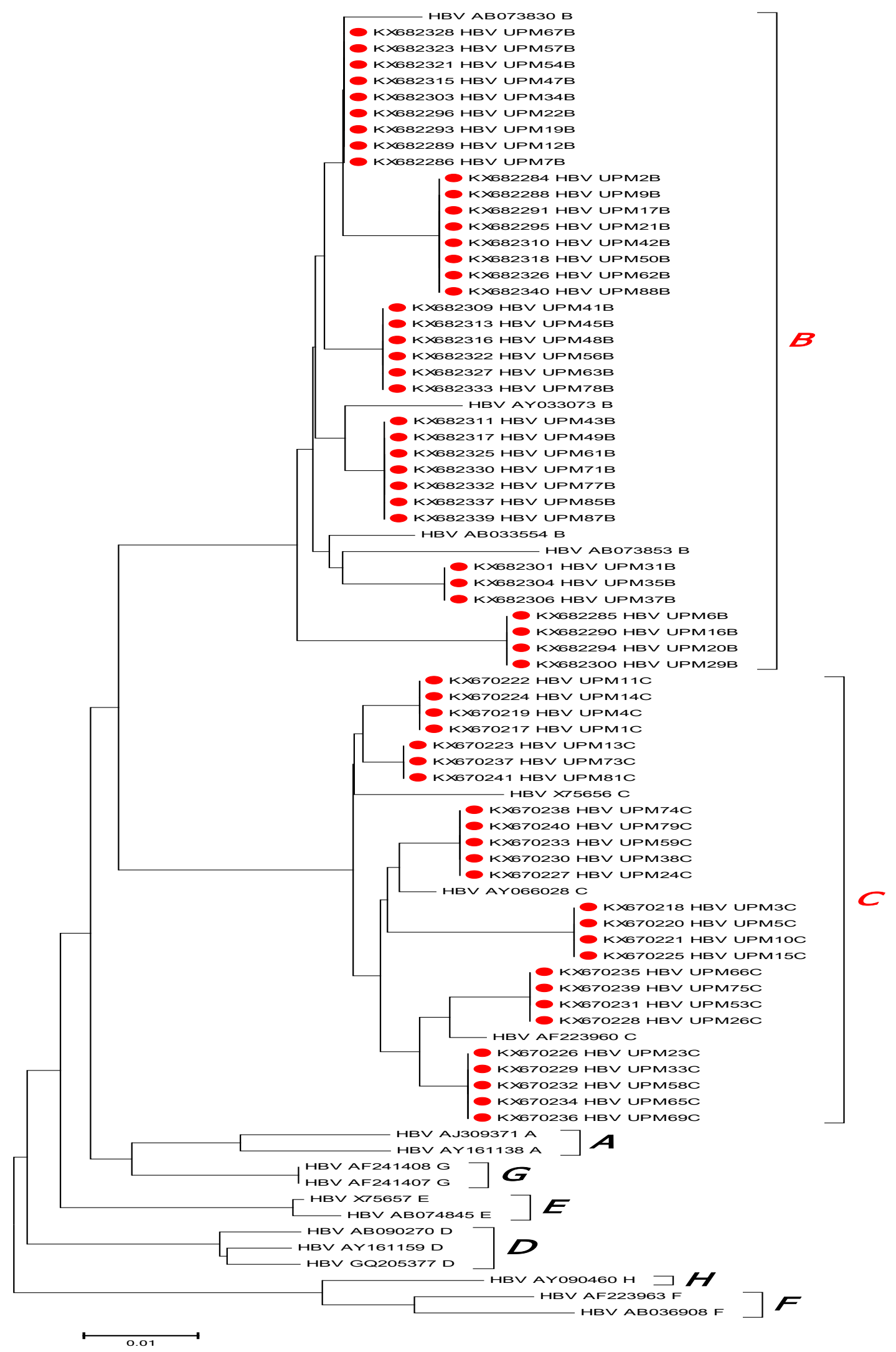

Figure 1: Malaysian hepatitis B virus isolates genotyping Phylogenetic tree.Small $S$ gene $(656 \mathrm{bp})$ of the HBsAg was used to generate the tree. The local isolates (red dots) are separated into two distinct clusters corresponding to genotypes $B$ and $C$. The alphabet A-H indicates genotypes. Sequences without dot are the reference sequences. 
Further analysis showed that HBV genotype B was grouped into three sub-types, with the majority, i.e. 64.91\% (37/57), belonging to B2 sub-type and serotype adw2; $12.28 \%(7 / 57)$ were of the B4 sub-type and ayw1 serotype, while the remaining 22.81\% (13/57) formed a cluster with the Ba sub-type (Fig 2) and ayw1 serotype (Fig 3), which specifically dominates in Asia and is usually referred to as "B Asia".

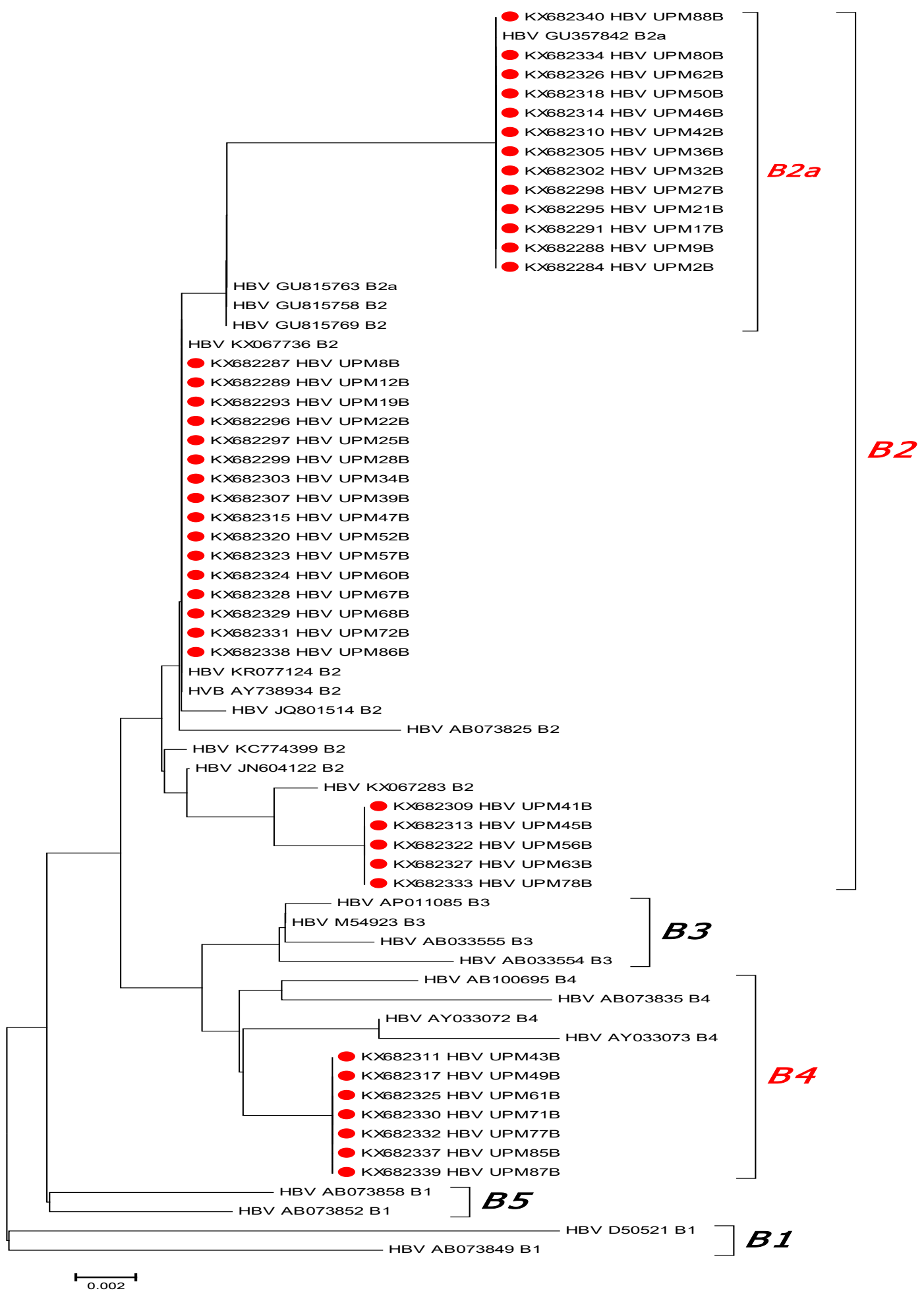

Figure 2: HBV genotype $B$ sub-genotyping of the local isolates (Red dots) using nucleotide of the small $S$ gene $(656 \mathrm{bp})$ of the HBsAg. Local HBVisolates formed clusters with the reference subtypesB4, $B 2$ and B2a (highlighted in red). Sequences without dot are the reference sequences. 


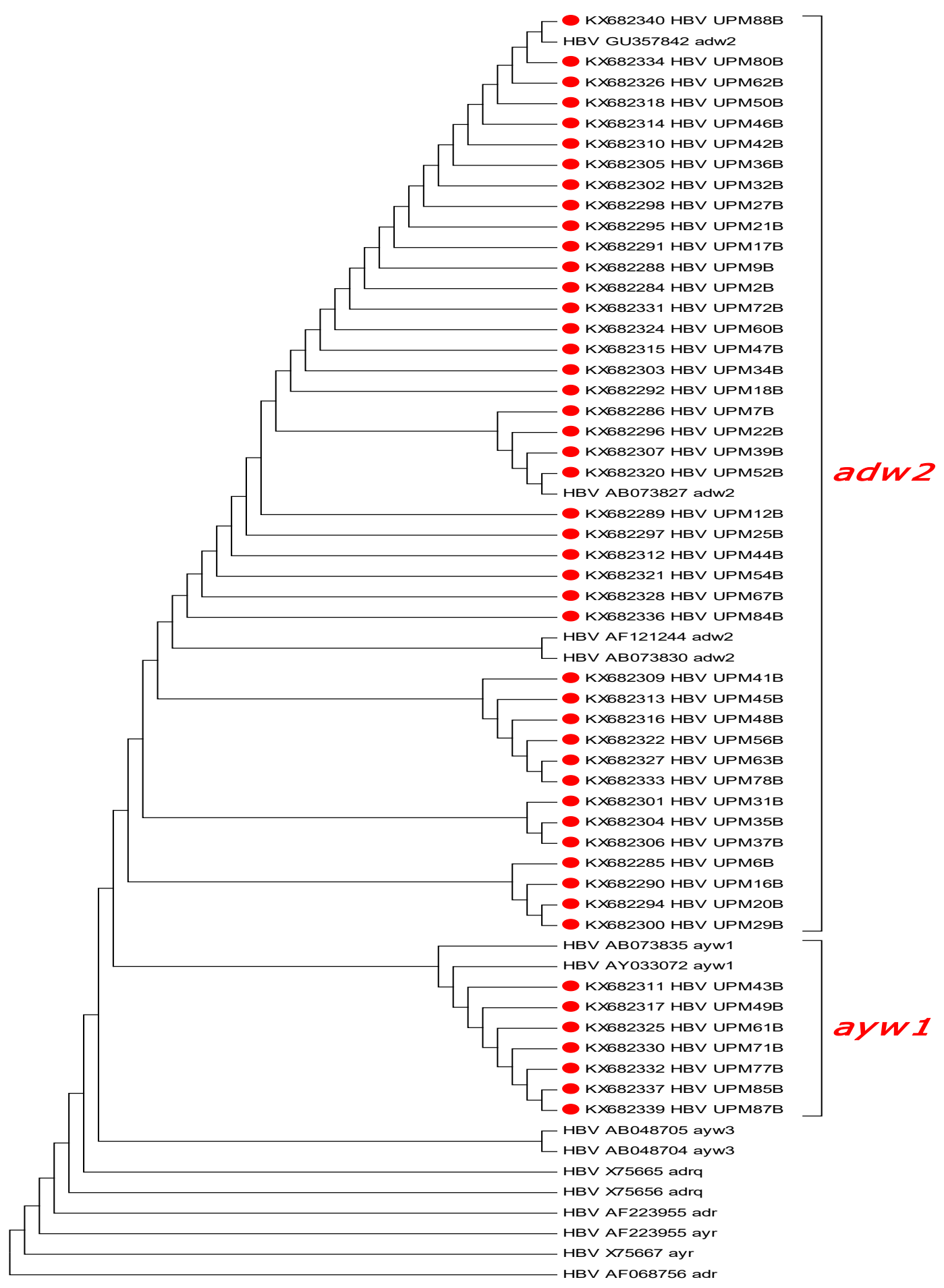

Figure 3: HBV genotype B serotyping of the local isolates (Red dots) using nucleotide of the small $S$ gene (656 bp) of the HBsAg. Local genotype B HBVisolates formed two clusters with the reference serotypes ayw1 and $a d w 2$ (highlighted in red). Sequences without dot are the reference sequences.

The $\mathrm{Ba}$ sub-type is a recombination of the $\mathrm{B}$ and $\mathrm{C}$ subtypes. HBV genotype $\mathrm{C}$ isolates were phylogenetically related to $\mathrm{C} 2$ and serotype ayr in a major cluster containing
$88 \%(22 / 25)$ of isolates, while the remaining $12 \%(3 / 25)$ formed a different cluster and were phylogenetically close to C4 (Fig 4) and serotype adrq (Fig 5). 


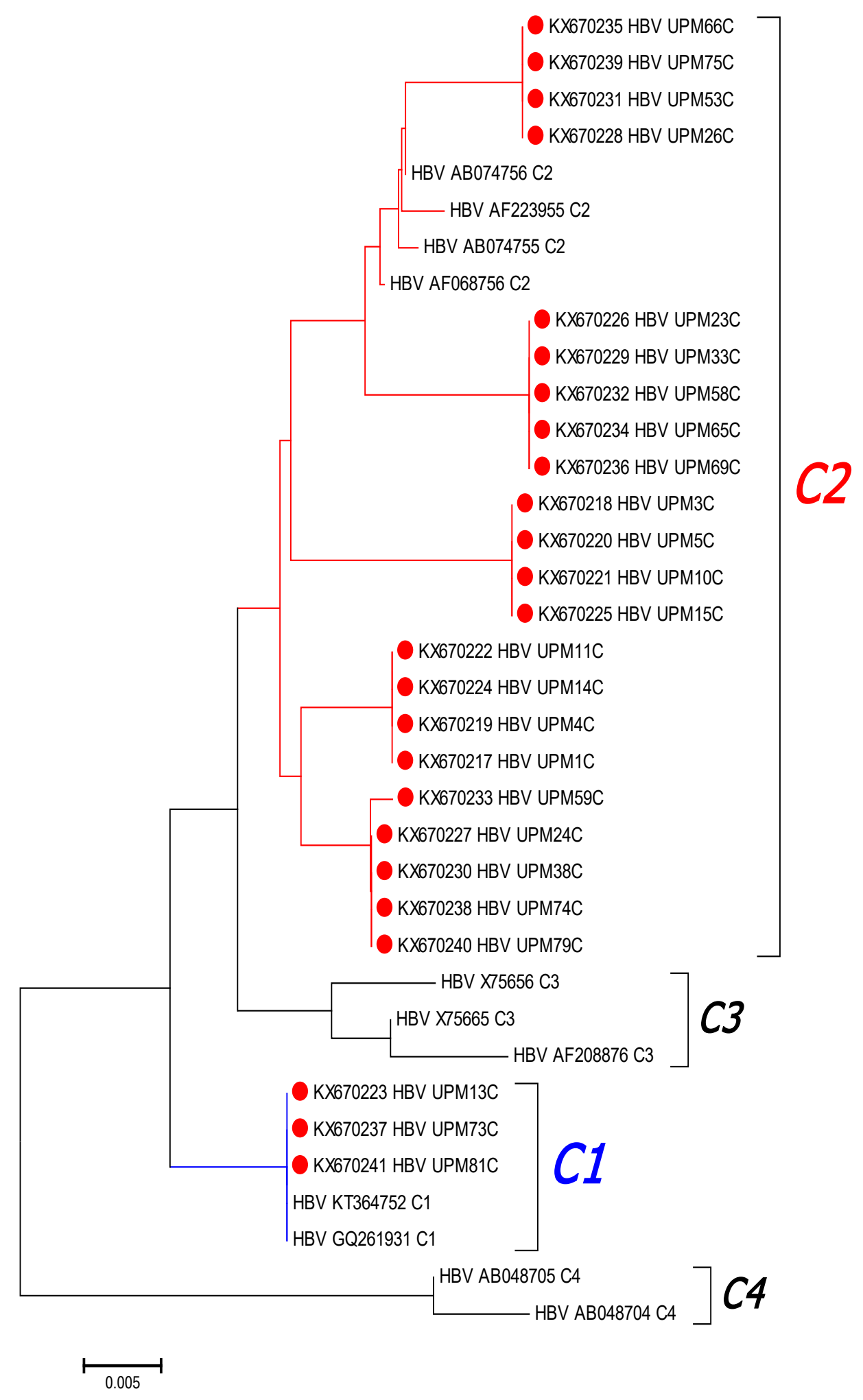

Figure 4: HBV genotype $C$ virus sub-genotyping of the local isolates (Red dots) using nucleotide sequences of the small $S$ gene (656 bp) of the HBsAg. The local isolates formed two clusters of subtypes C2 (red) and C1 (blue). C1-C4: subtypes. Sequences without dot are the reference sequences 


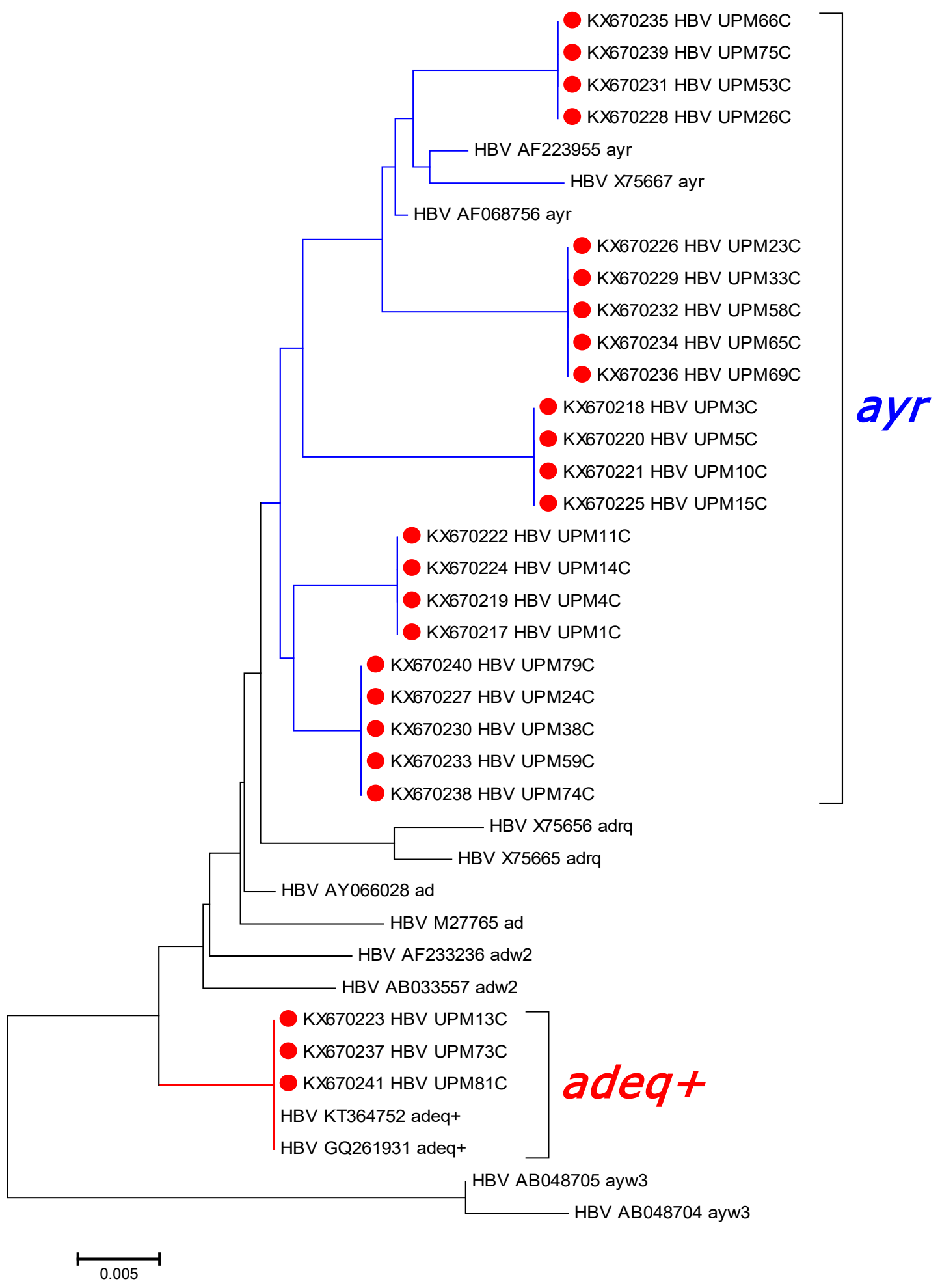

Figure 5: HBV genotype $C$ virus sero-typing of the local isolates (Red dots)

Using nucleotide sequences of the small $S$ gene (656 bp) of the HBsAg.

The majority of the local isolates belonged to the ayr (Blue) and only three of the isolates belonged to the adeq + (red). Sequences without dot are the references sequences. 
The hepatitis $\mathrm{C}$ virus that was found to be co-infected with $\mathrm{HBV}$ in this study was phylogenetically related to isolate D17763 from Japan and belonged to genotype 3 subtype a, forming a cluster with other reference isolates of similar genotypes and subtypes (Fig 6). Similarly, hepatitis E virus (HEV) co-infected with HBV phylogenetically formed a single cluster with isolates from China (AB108537), isolated from sporadic HEV infection cases and one from Japan (AB220974) isolated from a fulminant acute self-limiting $\mathrm{HEV}$ infection; this cluster belongs to genotype 4 (Fig 7). Hepatitis B genotype B was found to be co-infected with HCV genotype 3 a, while HEV genotype 4 was found to be co-infected with both genotypes $\mathrm{B}$ and $\mathrm{C}$ of HBV. The hepatitis $\mathrm{B}$ genotype was found to be significantly $(\chi 2=56.632 ; \mathrm{p}<0.01)$ associated with the clinical stage of infection as shown in table 2.

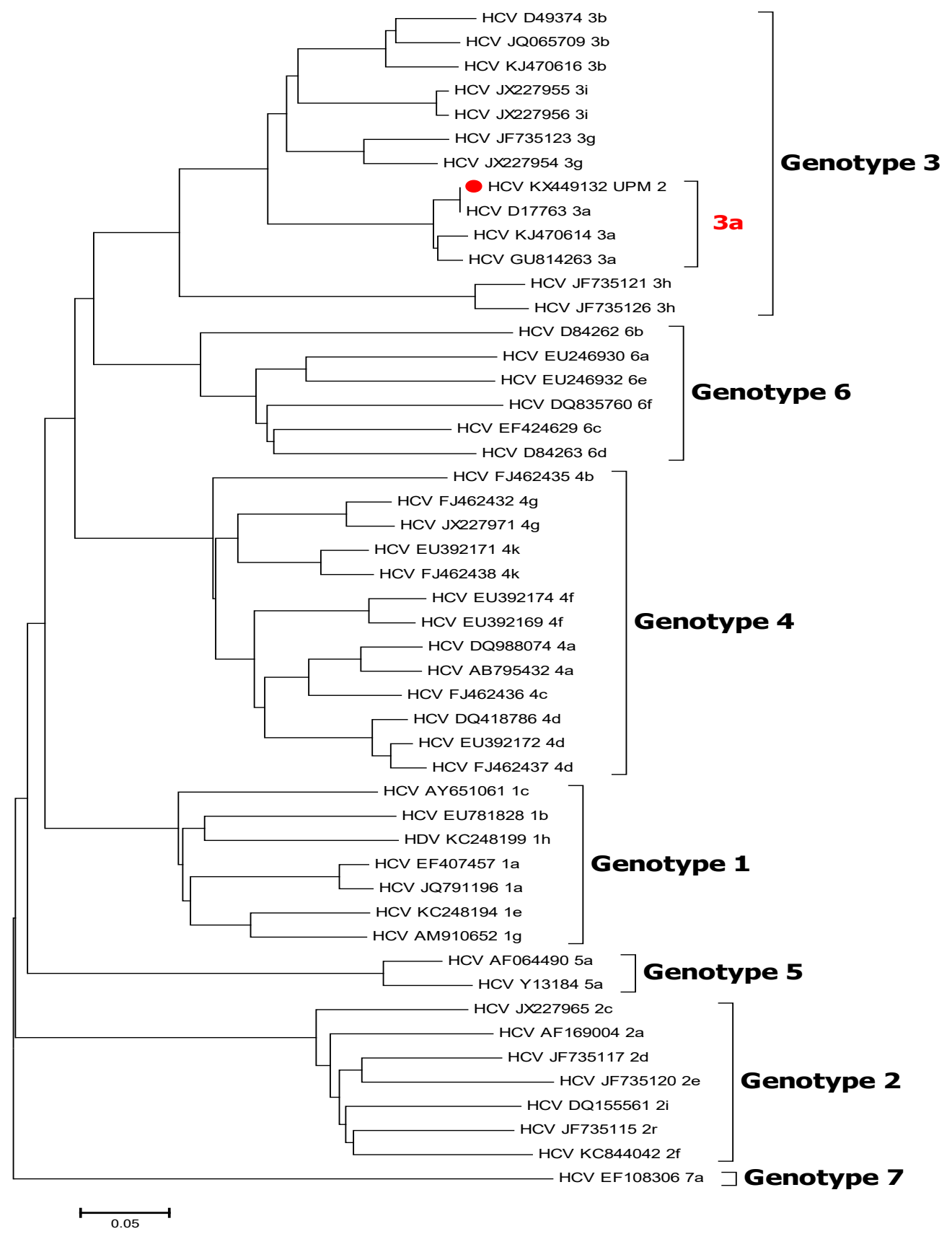

Figure 6: Hepatitis $C$ virus genotype and subtype inferred by phylogenetically using HCV capsid NS5B nucleotide sequence. The local isolate (Red dot) form a cluster with genotype 3 subtype $a$ (3a) as highlighted in red. Sequences without dot are the reference sequences. 


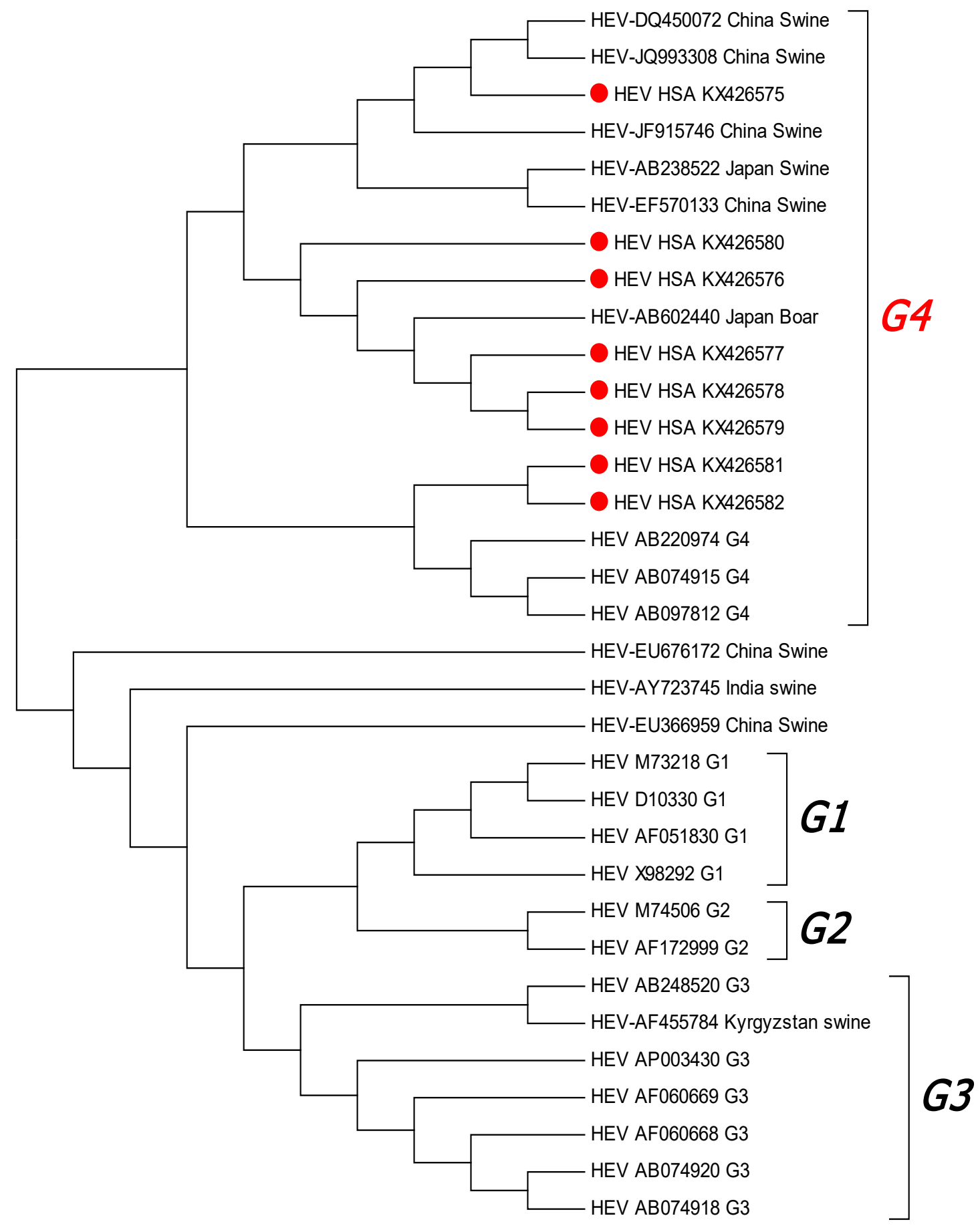

Figure 7: Hepatitis E virus genotyping using viral capsid OFR2 nucleotide sequences in generating the phylogenetic tree. The red dots indicate local isolates which forms cluster with genotype 4 (highlighted in red). G1-G4 indicates genotypes. Sequences without dot are the reference sequences. 
Table 2: Clinical stage of infection associated with hepatitis genotypes

\begin{tabular}{|c|c|c|c|c|}
\hline \multirow[t]{2}{*}{$\begin{array}{l}\text { Clinical } \\
\text { infection }\end{array}$} & \multicolumn{2}{|c|}{$\begin{array}{l}\text { Hepatitis B genotype } \% \\
(n=82)\end{array}$} & \multirow{2}{*}{$\begin{array}{l}\text { Hepatitis } \\
\text { genotype\% } \\
(n=1)\end{array}$} & \multirow{2}{*}{$\begin{array}{l}\text { Hepatitis E } \\
\text { genotype\% } \\
(n=8)\end{array}$} \\
\hline & $B(n=57)$ & $C(n=25)$ & & \\
\hline $\begin{array}{l}\text { Non-cirrhotic chronic } \\
\text { hepatitis B }\end{array}$ & $68.4(39)$ & $20.0(5)$ & 0 & $37.5(3)$ \\
\hline $\begin{array}{l}\text { Cirrhotic chronic hepatitis } \\
\text { B }\end{array}$ & $1.8(1)$ & $68(17)$ & 0 & $37.5(3)$ \\
\hline Hepatitis B acute flare & $29.8(17)$ & 0 & $100(1 / 1)$ & $12.5(1)$ \\
\hline $\begin{array}{l}\text { Hepatitis Bhepatocellular } \\
\text { carcinoma }\end{array}$ & 0 & $12(3)$ & 0 & $12.5(1)$ \\
\hline Total $(\%)$ & 100 & 100 & 100 & 100 \\
\hline
\end{tabular}

\section{Discussion}

In this study, we determined the proportion of hepatitis $\mathrm{B}$ co-infections and the clinical and genetic diversities of $\mathrm{HBV}, \mathrm{HCV}$ and HEV. The results showed $9.8 \%$ and $1.2 \%$ hepatitis B co-infection with $\mathrm{HEV}$ and $\mathrm{HCV}$, respectively, among Malaysian chronic hepatitis B patients. Hepatitis B and $\mathrm{C}$ co-infection was found to be very low among the Malaysian chronic hepatitis B infection patients at only $1.2 \%$. This is far lower than what was reported in India $(12.3 \%)^{20}$ and Taiwan $(8 \%)^{21}$, and closely related to what was reported (2.7\%) in Santo Antonio General hospital in Portugal ${ }^{22}$. On the other hand, the rate of hepatitis $\mathrm{E}$ co-infection with hepatitis B reported in this study was lower than what was reported in Chennai, India $(6.25 \%)^{23}$ and Bangladesh $(18.1 \%)^{24}$, and is much higher in Egypt $(56.7 \%)^{25}$. The results of our co-infected patients show increased levels of total bilirubin and liver enzymes with low albumin levels and normal platelet counts. This is in contrast to what was reported in a previous study suggesting that chronic hepatitis $\mathrm{B}$ infection may be inactive in the presence of HEV infection ${ }^{26 .}$ Similarly, HCV co-infection in chronic hepatitis B patients has been related to a poor prognosis and the development of cirrhosis or $\mathrm{HCC}^{27}$. This was confirmed by the present study, in which the only patient that was found to have an HCV super-infection presented with hepatitis B acute flare. The serological and biochemical test results suggest that co-infection with HEV contributed to liver inflammation than HVB infection with no HEV or HCV co-infection ${ }^{28}$. To date, there are only eight recognized hepatitis B gen- otypes, designated A to $\mathrm{H}^{29}$. However, as a result of whole gene sequencing, two additional genotypes that were proposed as I and J from Vietnam and Japan, respectively, were later confirmed to be recombinant $t^{30-32}$. In this study, our Malaysian HBV isolates were found to be 69.5\% (57/82) genotype B and 30.5\% (25/82) genotype $\mathrm{C}$, which are the dominant genotypes in Southeast Asia ${ }^{33}$. Variations in clinical outcomes have been associated with hepatitis B genotypes, in which genotype C or D-infected patients have more severe outcomes than genotype $\mathrm{A}$ or B-infected patients ${ }^{34}$. Hepatocellular carcinoma and liver cirrhosis are commonly diagnosed in patients infected with $\mathrm{HBV}$ genotype $\mathrm{C}$ or $\mathrm{D}$, more often than in those with genotype $\mathrm{A}$ or $\mathrm{B}^{35}$. This concurs with our findings, since 17 of the 25 genotype C-infected patients $(68 \%)$ also had liver cirrhosis and all the three patients with HCC in this study were infected with genotype $\mathrm{C}$ $(12 \%)$ viruses; the remaining $20 \%(5 / 25)$ genotype $\mathrm{C}$-infected patients were non-cirrhotic. In terms of the therapeutic response, $\mathrm{HBV}$ genotype A- or B-infected patients responded better to interferon treatment than genotype C- or D-infected patients ${ }^{36}$. Hepatitis B genotype B in this study was found to be associated with non-cirrhotic infections $(68.4 \%)$ and acute flares $(29.8 \%)$, with only one patient $(1.8 \%)$ with liver cirrhosis. Hepatitis B e antigen seroconversion and seroclearance are significant events in the HBV natural history, with a projected yearly incidence of $2 \%$ and $12 \%$, respectively ${ }^{37,38}$. Earlier HBeAg seroconversion is associated with better outcomes and late or absent $\mathrm{HBe} \mathrm{Ag}$ seroconversion leads to faster progression 
of chronic hepatitis to cirrhosis after multiple hepatitis flares $^{39}$. This is applicable to this study, as all our hepatitis B-infected cirrhotic patients were found to be $\mathrm{HBeAg}$ positive and the majority of patients with an acute flare (94.1\%) were also HBeAg positive, while the non-cirrhotic patients were $\mathrm{HBeAg}$ negative. Similarly, of the 57 genotype B-infected patients in this study, 64.9\% were $\mathrm{HBeAg}$ negative and $35.1 \%$ were positive. Interestingly, 92\% genotype $\mathrm{C}$-infected patients were $\mathrm{HBeAg}$ positive and $8 \%$ were negative, indicating lower $\mathrm{HBeAg}$ seroconversion rates with genotype $\mathrm{C}$ compared to genotype $\mathrm{B}$ infection, supported by similar findings in previous studies ${ }^{40}$.

This study also revealed that the majority, i.e. $64.91 \%$ (37/57) of HBV genotype B isolates belonged to the B2 subtype and serotype adw2, while $12.28 \%$ (7/57) were of the B4 subtype and ayw1 serotype; the remaining $22.81 \%$ (13/57) belonged to the Ba subtype, serotype ayw. The geographical distribution of these genotypes is similar to their sub-genotypes and has been shown to play a significant role in clinical outcomes and anti-viral therapy outcomes $^{41,42}$. Hepatitis B genotype B is made up of six sub-genotypes, B1 to B6, with B1 to B5 as the predominant genotypes in East Asia; B1 is mainly found in Japan, while B6 is predominant in the Arctic region and has been associated with fulminant hepatitis and better responses to interferon treatment.

Most hepatitis $\mathrm{B}$ genotype $\mathrm{C}$ isolates belonged to subtype C2, serotype ayr (88\%), while the remaining $12 \%$ belonged to sub-type $\mathrm{C} 4$, serotype adrq. Genotype $\mathrm{C}$ was subdivided into four sub-genotypes $(\mathrm{C} 1-\mathrm{C} 4)^{43}$, with $\mathrm{C} 1$ as the major sub-type in East Asia, C2 in SouthEast Asia and China, C3 in Oceania and C4 in aborigines of Austra$\mathrm{lia}^{44}$. An additional sub-genotype C5 was isolated in 2006 in the Philippines ${ }^{45}$, and sub-genotype C6 was isolated from Papua in Indonesia and confirmed in 2009 $9^{46}$. At same time, another isolate was confirmed to be sub-genotype C6 in the Philippines, ${ }^{47}$ and sub-genotype C7 was isolated in the Philippines and Indonesia ${ }^{48,49}$. The hepatitis $\mathrm{C}$ viruses in this study were found to be of genotype $3 \mathrm{a}$, which has been reported to be globally distributed ${ }^{50}$ and is thought to be associated with injectable drug use ${ }^{51}$. The Malaysian HEV isolates were found to be of genotype 4, which is a genotype exclusively found in Asia in both humans and domestic animals ${ }^{52,53}$.

\section{Conclusion}

In this study, an insight was provided into the genetic distributions of three hepatitis viruses $(\mathrm{B}, \mathrm{C}$ and $\mathrm{E})$ and the rate of $\mathrm{HBV}$ co-infection with $\mathrm{HCV}$ and HEV among Malaysian chronic hepatitis B patients. Hepatitis B, genotype $\mathrm{C}$ infection was found to be the most prevalent $(68 \%)$ and was related to liver cirrhosis and HCC while, genotype $\mathrm{B}$ was found to be associated with non-cirrhotic infections $(68.4 \%)$ and acute flares $(29.8 \%)$. The rate of co-infection was found to be $9.8 \%$ for $\mathrm{HBV}$ and $\mathrm{HEV}$ and $1.2 \%$ for $\mathrm{HBV}$ and $\mathrm{HCV}$; the remaining $89 \%$ of patients were mono-infected. HCV superinfection presented with hepatitis B acute flares. This co-infection played an important role in hepatitis B infection severity in terms of morbidity and mortality. However, this study is not without limitation and some of the limitations include; non-probability sampling techniques used in recruiting patients for this study, and insufficient clinical information collected for this research limits it findings and conclusions from been generalized.

\section{Acknowledgments}

The authors are grateful to the Faculty of Medicine and Health Sciences, Universiti Putra Malaysia and Fundamental Research Grant Scheme (FRGS) number 5524778 from Ministry of Higher Education Malaysia. Our sincere gratitude also goes to the staff and management of theHepatology Department, Hospital Selayang for their support and understanding during the period of sample collection.

\section{Conflict of interest}

None to declare.

\section{References}

1. Raihan, Ruksana. "Hepatitis in Malaysia: Past, Present, and Future." Euroasian Journal of Hepato-Gastroenterology. 2016; 6(1) 52-55. PubMed.

2. Ryerson AB, Eheman CR, Altekruse SF, Ward JW, Jemal A, Sherman RL, et al. Annual Report to the Nation on the Status of Cancer, 1975-2012, featuring the increasing incidence of liver cancer. Cancer. 2016;122(9):1312-37. PubMed.

3. Ferlay J, Shin HR, Bray F, Forman D, Mathers C, Parkin DM. Estimates of worldwide burden of cancer in 2008: GLOBOCAN 2008. International Journal of Cancer. 2010;127(12):2893-917. 
4. Lavanchy D. Evolving epidemiology of hepatitis C virus. Clinical Microbiology and Infection. 2011;17(2):107-15.

5. Wasitthankasem R, Vongpunsawad S, Siripon N, Suya C, Chulothok P, Chaiear K, et al. Genotypic distribution of hepatitis $\mathrm{C}$ virus in Thailand and Southeast Asia. PloS One. 2015;10(5):e0126764.

6. Li CS, Chan PK, Tang JW. Molecular epidemiology of hepatitis $\mathrm{C}$ genotype 6 a from patients with chronic hepatitis C from Hong Kong. Journal of Medical Virology. 2009;81(4):628-33.

7. Hajarizadeh B, Grebely J, Dore GJ. Epidemiology and natural history of HCV infection. Nature Reviews Gastroenterology and Hepatology. 2013;10(9):553-62.

8. Magiorkinis G, Magiorkinis E, Paraskevis D, Ho SY, Shapiro B, Pybus OG, et al. The global spread of hepatitis $\mathrm{C}$ virus $1 \mathrm{a}$ and $1 \mathrm{~b}$ : a phylodynamic and phylogeographic analysis. PLoS Med. 2009;6(12): e1000198. PubMed.

9. Flores R, Minoia S, Carbonell A, Gisel A, Delgado S, López-Carrasco A, et al. Viroids, the simplest RNA replicons: how they manipulate their hosts for being propagated and how their hosts react for containing the infection. Virus Research. 2015;209:136-45. PubMed .

10. Noureddin M, Gish R. Hepatitis delta: epidemiology, diagnosis and management 36 years after discovery. Current Gastroenterology reports. 2014;16(1):1-8.

11. Sureau C, Negro F. The hepatitis delta virus: Replication and pathogenesis. Journal of Hepatology. 2016;64(1):S102-S16.

12. Khuroo MS, Khuroo MS. Hepatitis E: an emerging global disease-from discovery towards control and cure. Journal of Viral Hepatitis. 2016;23(2):68-79.

13. Khuroo MS, Khuroo MS, Khuroo NS. Hepatitis E: Discovery, global impact, control andcure. World J Gastroenterol. 2016;22(31):7030-45.

14. Marik PE. Acute and Chronic Liver Disease. Evidence-Based Critical Care: Springer, 2015. p. 523-50.

15. Govindarajan S, Chin KP, Redeker AG, Peters RL. Fulminant B viral hepatitis: role of delta agent. Gastroenterology. 1984;86(6):1417-20. PubMed.

16. Yu G, Chi X, Wu R, Wang X, Gao X, Kong F, et al. Replication Inhibition of Hepatitis B Virus and Hepatitis C Virus in Co-Infected Patients in Chinese Population. PloS one. 2014;10(9): e0139015-e. PubMed.

17. Hudu S, Harmal N, Saeed M, Alshrari A, Malik Y, Niazlin M, et al. Naturally occurring hepatitis B virus surface antigen mutant variants in Malaysian blood donors and vaccinees. European Journal of Clinical Microbiology \& Infectious Diseases. 2015;34(7):1349-59.

18. Ren F, Zhao C, Wang L, Wang Z, Gong X, Song $\mathrm{M}$, et al. Hepatitis $\mathrm{E}$ virus seroprevalence and molecular study among blood donors in China. Transfusion. 2014;54(3pt2):910-7.

19. Saha K, Firdaus R, Biswas A, Mukherjee A, Sadhukhan P. A novel nested reverse-transcriptase polymerase chain reaction method for rapid hepatitis $C$ virus detection and genotyping. Indian Journal of Medical Microbiology. 2014;32(2):130.

20. Gholamreza R, Shahryar S, Abbasali K, Hamidreza J, Abdolvahab M, Khodaberdi K, et al. Seroprevalence of hepatitis B virus and its co-infection with hepatitis D virus and hepatitis $\mathrm{C}$ virus in Iranian adult population. Indian Journal of Medical Sciences. 2007;61(5):263.

21. Chu C-M, Yeh C-T, Liaw Y-F. Low-level viremia and intracellular expression of hepatitis B surface antigen (HBsAg) in HBsAg carriers with concurrent hepatitis $\mathrm{C}$ virus infection. Journal of Clinical Microbiology. 1998;36(7):2084-6.

22. Barros H, Miranda HP, Silvestre F. Hepatitis $C$ virus antibodies in asymptomatic chronic carriers of hepatitis B surface antigen. Acta Médica Portuguesa. 1994;7:30-4.

23. Singh A, Singh S, Ansari M, Irshad M. Co-infectivity of hepatitis $\mathrm{B}$ virus and hepatitis $\mathrm{E}$ virus. BMC Infectious Diseases. 2011;12(Suppl 1):P1-P.

24. Sheikh A, Sugitani M, Kinukawa N, Moriyama M, Arakawa Y, Komiyama K, et al. Hepatitis e virus infection in fulminant hepatitis patients and an apparently healthypopulation in Bangladesh. The Americanjournal of Tropical Medicine and Hygiene. 2002;66(6):721-4.

25. Zaki MS, Salama OS, Mansour FA, Hossein S. Hepatitis $\mathrm{E}$ virus coinfection with hepatotropic viruses in Egyptian children. Journal of microbiology, immunology, and infection = Wei mian yu gan ran za zhi. 2008;41(3):254-8.

26. Cheng S, Mai L, Zhu F, Pan X, Sun H, Cao H, et al. Influence of chronic HBV infection on superimposed acute hepatitis E. World Journal of Gastroenterology: WJG. 2013;19(35):5904-9.

27. Liaw Y, Chen Y, Sheen I, Chien R, Yeh C, Chu C. Impact of acute hepatitis $C$ virus superinfection in patients with chronic hepatitis B virus infection. Gastroenterology. 2004;126(4):1024-9. PubMed.

28. Salam GD, Kumar A, Kar P, Aggarwal S, Husain A, Sharma S. Serum tumor necrosis factor-alpha level in 
hepatitis E virus-related acute viral hepatitis and fulminant hepatic failure in pregnant women. Hepatology Research. 2013;43(8):826-35. PubMed.

29. Kramvis A, Kew M, François G. Hepatitis B virus genotypes. Vaccine. 2005;23(19):2409-23.

30. Huy T'T'T, Ngoc TT, Abe K. New complex recombinant genotype of hepatitis B virus identified in Vietnam. JOURNAL OF VIROLOGY. 2008;82(11):5657-63. PubMed.

31. Thuy PTB, Alestig E, Liem NT, Hannoun C, Lindh $\mathrm{M}$. Genotype $\mathrm{X} / \mathrm{C}$ recombinant (putative genotype I) of hepatitis B virus is rare in Hanoi, Vietnam-Genotypes B4 and C1 predominate. Journal of Medical Virology. 2010;82(8):1327-33.

32. Tatematsu K, Tanaka Y, Kurbanov F, Sugauchi F, Mano S, Maeshiro T, et al. A genetic variant of hepatitis $B$ virus divergent from known human and ape genotypes isolated from a Japanese patient and provisionally assigned to new genotype J. JOURNAL OF VIROLOGY. 2009;83(20):10538-47.

33. Mahtab M-A, Rahman S, Khan M, Karim F. Hepatitis B virus genotypes: an overview. Hepatobiliary Pancreat Dis Int. 2008;7(5):457-64.

34. Kao J-H, Chen P-J, Lai M-Y, Chen D-S. Hepatitis B genotypes correlate with clinical outcomes in patients with chronic hepatitis B. Gastroenterology. 2000;118(3):5549.

35. Yu M-W, Yeh S-H, Chen P-J, Liaw Y-F, Lin C-L, Liu C-J, et al. Hepatitis B virus genotype and DNA level and hepatocellular carcinoma: a prospective study in men. Journal of the National Cancer Institute. 2005;97(4):265-72.

36. Kao J-H, Wu N-H, Chen P-J, Lai M-Y, Chen D-S. Hepatitis B genotypes and the response to interferon therapy. Journal of Hepatology. 2000;33(6):998-1002.

37. Liu J, Yang HI, Lee MH, Lu SN, Jen CL, Wang LY, et al. Incidence and determinants of spontaneous hepatitis B surface antigen seroclearance: a community-based follow-up study. Gastroenterology. 2010;139(2):474-82. PubMed.

38. Hsu YS, Chien RN, Yeh CT, Sheen I, Chiou HY, Chu $\mathrm{CM}$, et al. Long-term outcome after spontaneous $\mathrm{HBeAg}$ seroconversion in patients with chronic hepatitis B. Hepatology. 2002;35(6):1522-7. PubMed.

39. Chu CM, Liaw YF. Chronic hepatitis B virus infection acquired in childhood: special emphasis on prognostic and therapeutic implication of delayed HBeAg seroconversion. Journal of viral hepatitis. 2007;14(3):147-52.

40. Lin CL, Kao JH. The clinical implications of hepatitis
B virus genotype: recent advances. Journal of gastroenterology and hepatology. 2011;26(s1):123-30.

41. Kramvis A, Kew M. Relationship of genotypes of hepatitis $B$ virus to mutations, disease progression and response to antiviral therapy. Journal of viral hepatitis. 2005;12(5):456-64.

42. Kao JH. Hepatitis B viral genotypes: clinical relevance and molecular characteristics. Journal of gastroenterology and bepatology. 2002;17(6):643-50.

43. Norder H, Couroucé A-M, Coursaget P, Echevarria J, M e, Lee S-D, et al. Genetic diversity of hepatitis B virus strains derived worldwide: genotypes, subgenotypes, and HBsAg subtypes. Intervirology. 2004;47(6):289-309. PubMed.

44. Sugauchi F, Mizokami M, Orito E, Ohno T, Kato H, Suzuki S, et al. A novel variant genotype $C$ of hepatitis $B$ virus identified in isolates from Australian Aborigines: complete genome sequence and phylogenetic relatedness. Journal of general virology. 2001;82(4):883-92.

45. Sakamoto T, Tanaka Y, Orito E, Clavio J, Sugauchi F, Ito K, et al. Novel subtypes (subgenotypes) of hepatitis $\mathrm{B}$ virus genotypes $\mathrm{B}$ and $\mathrm{C}$ among chronic liver disease patients in the Philippines. Journal of general virology. 2006;87(7):1873-82.

46. Utsumi T, Lusida MI, Yano Y, Nugrahaputra VE, Amin M, Hayashi Y, et al. Complete genome sequence and phylogenetic relatedness of hepatitis B virus isolates in Papua, Indonesia. Journal of clinical microbiology. 2009;47(6):1842-7.

47. Cavinta L, Sun J, May A, Yin J, von Meltzer M, Radtke $\mathrm{M}$, et al. A new isolate of hepatitis B virus from the Philippines possibly representing a new subgenotype C6. Journal of medical virology. 2009;81(6):983-7.

48. Cavinta L, Cao G, Schaefer S. Description of a new hepatitis B virus C6 subgenotype found in the Papua province of Indonesia and suggested renaming of a tentative C6 subgenotype found in the Philippines as subgenotype C7. Journal of clinical microbiology. 2009;47(9):30689.

49. Depamede SN, Surayah K, Tsuda F, Ichiyama K, Takahashi M, Okamoto H. A nationwide molecular epidemiological study on hepatitis B virus in Indonesia: identification of two novel subgenotypes, B8 and C7. Archives of virology. 2009;154(7):1047-59.

50. Stumpf M, Pybus O. Genetic diversity and models of viral evolution for the hepatitis $\mathrm{C}$ virus. FEMS microbiology letters. 2002;214(2):143-52.

51. Kalinina O, Norder H, Vetrov T, Zhdanov K, Barzu- 
nova M, Plotnikova V, et al. Shift in predominating subtype of HCV from 1b to 3a in St. Petersburg mediated by increase in injecting drug use. Journal of medical virology. 2001;65(3):517-24.

52. Okamoto H. Genetic variability and evolution of hepatitis E virus. Virus research. 2007;127(2):216-28.
53. Mutai B, Wainaina J, Magiri C, Nganga J, Ithondeka P, Njagi O, et al. Vector-Borne and Zoonotic Diseases. 2013. 54. Hasegawa M, Kishino H, Yano T-a. Dating of the human-ape splitting by a molecular clock of mitochondrial DNA. Journal of molecular evolution. 1985;22(2):160-74. 